\title{
Popliteal Pterygium Syndrome
}

\section{Evidence for a Severe Autosomal Recessive Form*}

\author{
CHRISTOS S. BARTSOCAS and CONSTANTINE V. PAPAS
}

From the Paediatric Unit, 'Aghia Sophia' Children's Hospital, Athens 608, Greece

The term 'popliteal pterygium syndrome' has been used to distinguish a constellation of congenital anomalies characterized by cleft palate, with or without cleft lip, lip pits, popliteal and other webs, toenail dysplasia, syndactyly, aplasia of the labia majora, and other anomalies. The syndrome may be associated with mental retardation. About 48 cases of this inherited syndrome have been reported in the literature $\nmid$ since Trélat's first description in 1869. The genetic pattern by which the popliteal pterygium syndrome is transmitted has however not yet been firmly established (Smith, 1970). An additional family with this syndrome is reported.

\section{Family Report}

The parents were third cousins. The father was 39 and the mother 35 years old. They were both healthy and no malformations had been reported in the family for at least 3 generations. As shown in the pedigree (Fig. 1) the mother had 9 pregnancies, 4 of which produced affected offspring. The first child (VI.1), a female, was reported as normal, but died at 6 months of age with pneumonia. Two miscarriages occurred during the 2nd and 3rd months of pregnancy (VI.2 and VI.3). The fourth pregnancy resulted in a full-term normal delivery of a newborn with multiple congenital anomalies of the face, consisting of a depressed nose, small oral opening, arthrogryposis, and severely malformed extremities. The 5th child (VI.5) a female born in 1959 was examined and found to be healthy. The next pregnancy resulted in a female infant with congenital heart disease (VI.6) who died at 6 months of age. No other anomalies were present, but neither diagnostic

\footnotetext{
Received 3 January 1972.

- Part of this article was presented at the IV International Congress of Human Genetics held in Paris, 6-11 September 1971.

† Wolff, 1889; Basch, 1891, Rydygier, 1891; Basch, 1892; Fischer, 1893; Hackenbroch, 1924; Matolcsy, 1936; Aberle-Horstenegg, 1937; Kopits, 1937; Marquardt, 1937/1938; Edwards, 1938; Schramm, 1940; Lewis, 1948; Schönenberg, 1955; Champion and Cregan, 1959; Dahmen, 1961; Rosselli and Gulienetti, 1961; Fèvre and Languepin, 1962; Klein, 1962; Hecht and Jarvinen, 1967; Gorlin, Sedana, and Cervenka, 1968; Kind, 1970; O'Brien et al, 1970; Pfeiffer, Tünte, and Reinken, 1970.
}

studies nor a necropsy were performed. A stillborn male (VI.7) the product of a 5-month gestation, had syndactyly. The 8th child (VI.8), a female, died on the 2nd day of life from aspiration pneumonia possibly caused by an existing facial cleft defect. There was extreme facial similarity with VI.4 and the proposita (VI.9). Fusion syndactyly of the hand was striking.

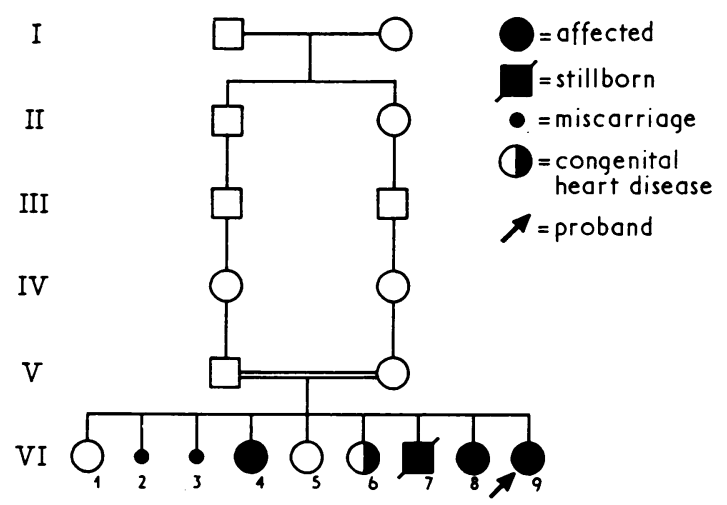

FIG. 1. Pedigree of the present family. Many relatives were omitted to show better the parental consanguinity.

Case Report. The proposita (VI.9) was delivered by Caesarean section at 36 weeks' gestation. Decreased fetal activity was noted. She weighed $2750 \mathrm{~g}$ and measured $45 \mathrm{~cm}$ in length. Head circumference was $31 \mathrm{~cm}$. The infant was in no distress, but presented several severe congenital anomalies. These consisted of microcephaly, ankyloblepharon filiforme, corneal aplasia, filiforme bands between the jaws, cleft palate, and incomplete left cleft lip extending downwards from the left nostril. The nose was hypoplastic (Fig. 2).

There was bilateral thumb aplasia and fusion syndactyly of the hands with a single nail. There was also syndactyly of the toes and clubbed feet. Popliteal pterygia were present on both sides. Aplasia of the labia majora was also present.

Laboratory Studies. Radiological examination of the patient revealed the skull to be normal. No intracranial calcifications were noted. The mandible was hypoplastic and receded. Orbital films revealed a normal 


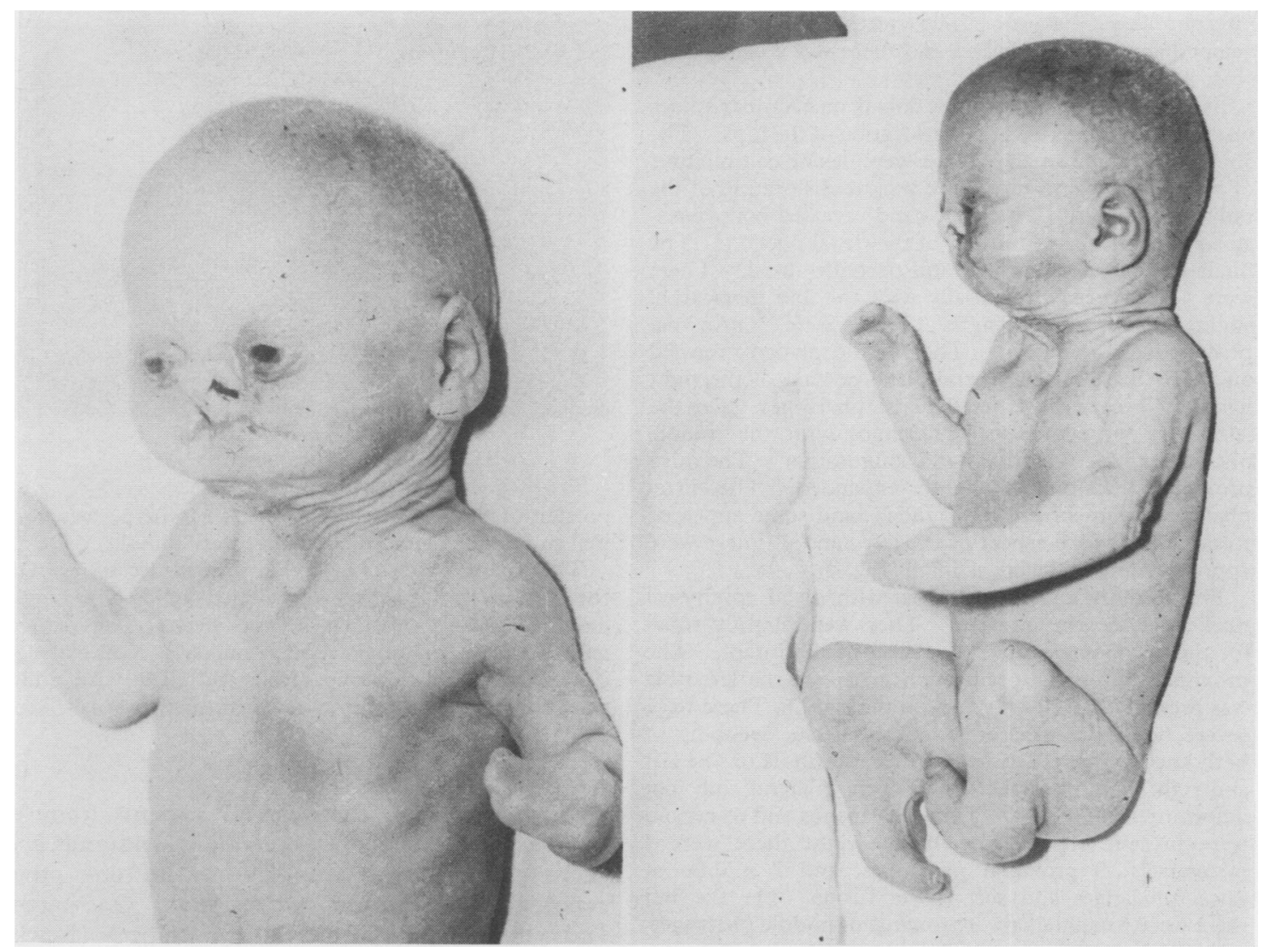

FIG. 2. The proband is shown in both photographs. Micrognathia fusion syndactyly of hands and the popliteal pterygia are shown on the left; the facial anomalies on the right.

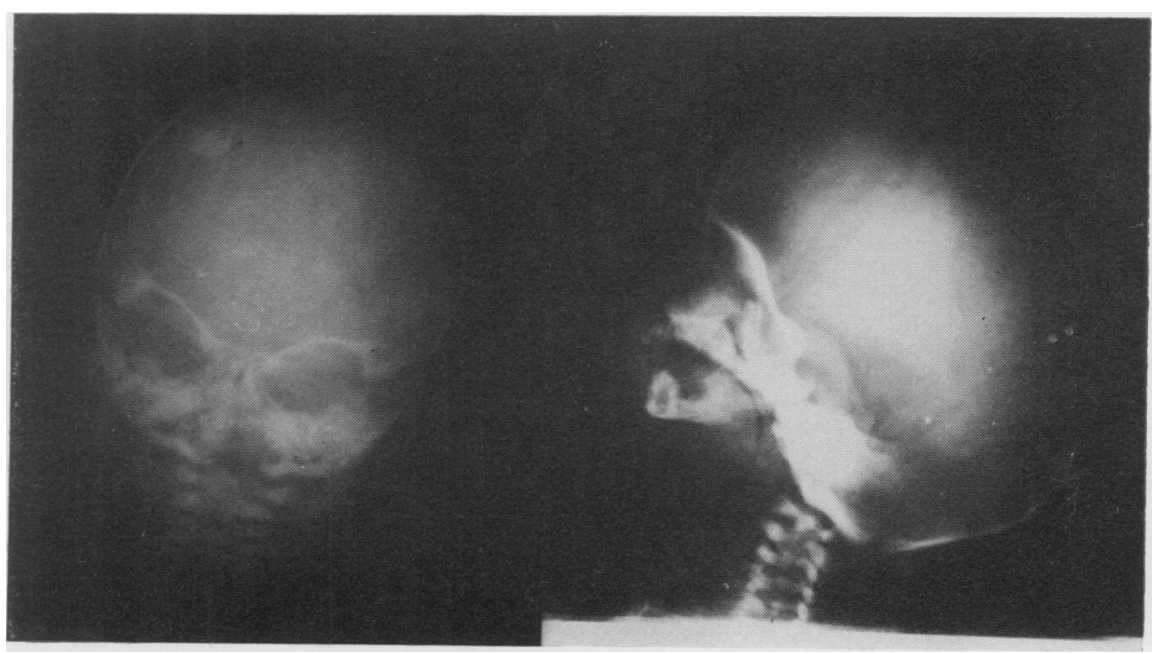

Fig. 3. Skull $x$-rays of the proposita. 
interpupillary distance. The teeth were underdeveloped and poorly calcified and there was a cleft palate (Fig. 3).

Examination of the cervical, dorsal, and lumbar spines was normal. There was no dislocation of the hips. The shoulders were normal. There were flexion contractures of both elbow joints and there was no dislocation of the radius and ulnae. The right hand revealed bony synostosis and soft tissue tumour of the distal portion. The phalanges were malformed and partially fused. There were 4 metacarpals bilaterally with the 2nd metacarpal slightly increased in length. There were 3 proximal phalanges on the right. The middle phalanx formed one bony mass in the central distal portion of the right hand. There were 2 small distal phalanges. On the left there were proximal phalanges with the middle phalanx expanded and bifid in configuration. The third proximal phalanx was slightly expanded. The distal phalanges were small and rounded, and some appeared fused at the radial aspect of the left hand. There were approximately 5 phalanges in all (Fig. 4).

Both femora appeared normal with distal epiphyseal ossification centres present. They were slightly small for the chronological age ( 2 weeks) of the infant. The proximal epiphyseal ossification centre of the left tibia was present. None was seen on the right. There were severe flexion contractures and soft tissue webbing of both knee joints. The lower tibia and fibula on the left and right were normal. There were bilateral club foot deformities of the feet. Talus calcaneous and os cuboid were present bilaterally. On the right there were 3 metatarsals, 3 proximal phalanges, and 2 middle or distal phalanges and soft tissue fusion. On the left there were 4 metatarsals, 3 proximal or middle phalanges, and 2 distal phalanges. There was soft tissue fusion. There was also a soft tissue bulge in the lateral distal

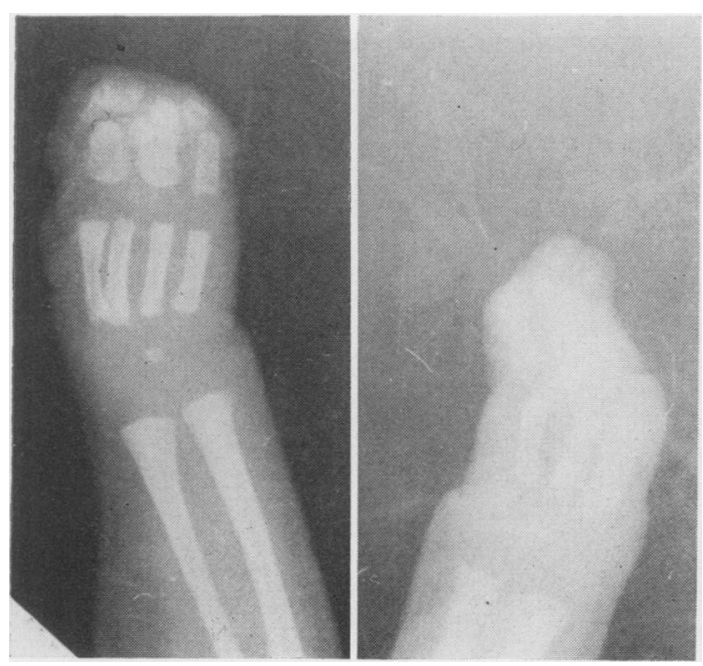

FIG. 4. $X$-rays of the hands of the proposita.

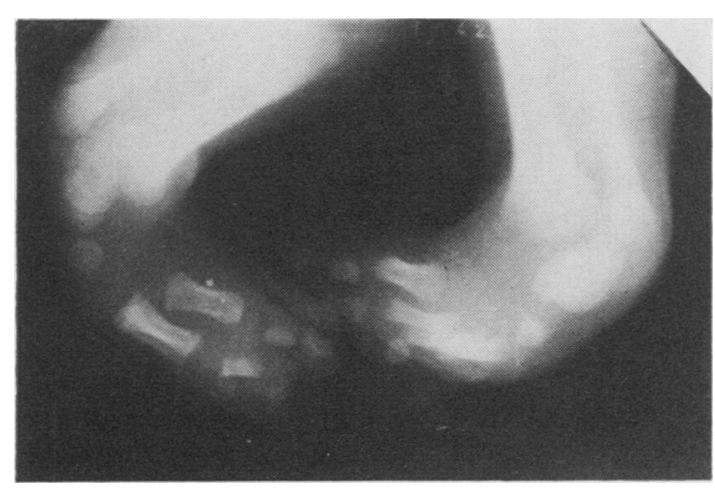

FIG. 5. $X$-rays of the proposita's feet.

portion of the left foot (Fig. 5). A karyotype was normal and no biochemical anomalies were found.

The infant was fed through a nasogastric tube. On the 3rd day of life she developed mild physiologic jaundice, which subsided in one week. The patient gained weight on tube feeding, but at 9 weeks of age developed Gram-negative sepsis and died. An additional finding at necropsy was a bicornuate uterus.

\section{Discussion}

In the literature there are 47 patients from 30 families with the popliteal pterygium syndrome, and there was parental consanguinity in one other report (Rosselli and Gulienetti, 1961). One parent and child were affected in 6 instances (Lewis, 1948; Klein, 1962; Hecht and Jarvinen, 1967; Kind, 1970; Pfeiffer et al, 1970), and in one case one of the grandparents was partially affected (Champion and Cregan, 1959). Including the present family, there are 10 familial instances of this syndrome with more than one individual affected (Matolcsy, 1936; Kopits, 1937; Lewis, 1948; Champion and Cregan, 1959; Klein, 1962; Hecht and Jarvinen, 1967; Kind, 1970; Pfeiffer et al, 1970), making a total of 28 familial cases and 24 isolated patients (Fig. 6).

The genetics of the syndrome remain unclear. On the basis of the families they studied, Hecht and Jarvinen (1967) suggested that the popliteal pterygium syndrome may be inherited as a dominant trait. From most families with 2 members affected there is evidence for autosomal dominant inheritance. X-linkage is ruled out by male-to-male transmission (Lewis, 1948; Pfeiffer et al, 1970). The expression of this dominant gene was noted to vary. Some affected individuals had very few anomalies. This could also support the idea that some individuals with the gene may be phenotypically normal. Some evidence of this is exhibited in Champion and Cregan's family (1959), 


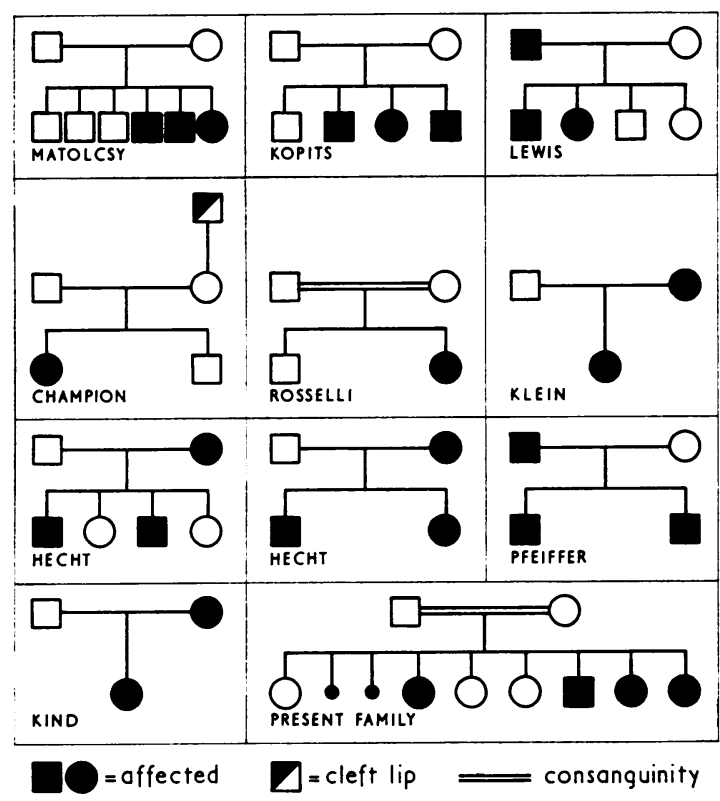

FIG. 6. Pedigrees of familial cases of the popliteal pterygium syndrome reported in the literature.

where the mother of 2 affected individuals was normal; but her father, the patients' maternal grandfather, had a cleft lip.

The frequent occurrence in sibs without affected parents, the consanguinity in 2 instances, and the ratio of affected to non-affected individuals in families with non-affected parents suggests an autosomal recessive inheritance. Thus it is likely that a constellation of anomalies is similar to the autosomal dominant syndrome.

Popliteal pterygium syndrome which is inherited as an autosomal dominant trait may exhibit incomplete penetrance and variable expressivity within each family. Many sporadic cases belong to this group.

Popliteal pterygium syndrome inherited by an autosomal recessive mode seems to be a more severe form with many anomalies and mental retardation present in some cases. The family presented here belongs to the second group.

\section{Summary}

A family with 4 children very severely affected with the popliteal pterygium syndrome is reported. The proposita had mental retardation, absent corneae, multiple webs (oral and popliteal in extreme forms), cleft palate, micrognathia, and syndactyly of fingers and toes, with hypoplastic or absent phalanges and nail aplasia. She had hypoplastic labia majora and a bicornuate uterus. She lived only 9 weeks. All other affected sibs presented similar anomalies and died within the first week of life. The parents were third cousins. No malformations were reported in the family in the previous 3 generations. This is the second instance of parental consanguinity in the syndrome.

The genetic pattern by which the popliteal pterygium syndrome is inherited has not yet been firmly established. Reviewing the evidence from the 31 families for which reports are available suggests two different forms of the syndrome. (1) Popliteal pterygium syndrome with autosomal dominant inheritance. There is incomplete penetrance and variable expressivity within each family. Many sporadic cases have been reported and patients have normal intelligence. (2) Popliteal pterygium syndrome with autosomal recessive inheritance. This form is postulated because of the frequent occurrence in sibs without affected parents and consanguinity in 2 pedigrees. The present family belongs to the second group.

\section{REFERENCES}

Aberle-Horstenegg, W. (1937). Flughautbildung zwischen Oberund Unterschenkel mit abnormer Muskelbildung. Zeitschrift für Orthopädie und ihre Grenzgebiete, 67, 21-29.

Basch, K. (1891). Ueber sogenannte Flughautbildung am Menschen. Prager Medizinische Woehenschrift, 16, 572-573.

Basch, K. (1892). Ein weiterer Fall von sog. Flughautbildung. Prager Medizinische Wochenschrift, 17, 289-291.

Champion, R. and Cregan, J. C. F. (1959). Congenital popliteal webbing in siblings. Fournal of Bone and foint Surgery, 41B, 355357.

Dahmen, G. (1961). Ueber die Versorgung einer doppelseitigen Kniestreckhemmung wegen Flügelfell mit einem provisorischen Knie-Ruhebein. Zeitschrift für Orthopädie und ihre Grenzgebiete, 95, 112-113.

Edwards, L. M. (1938). Webbing of lower limbs, associated with congenital bilateral contractions of flexor muscles of elbow and wrist. Proceedings of the Royal Society of Medicine, 31, 1053.

Fèvre, M. and Languepin, A. (1962). Les brides cruro-jambières contenant le nerf sciatique. Le syndrome bride poplitée et malformations multiples. Presse Médicale, 70, 615-618.

Fischer, H. (1893). Ein Fall von sogennanter Flughautbildung zwischen Ober- und Unterschenkel. Prager Medizinische Wochenschrift, 18, 579-581.

Gorlin, R. J., Sedana, H. O., and Cervenka, J. (1968). Popliteal pterygium syndrome. Pediatrics, 41, 503-509.

Hackenbroch, M. (1924). Ueber einen Fall von Kongenitaler Kontraktur der Kniegelenke mit Flughautbildung. Zeitschrift für Orthopädie und ihre Grenzgebiete, 43, 508-524.

Hecht, F. and Jarvinen, J. M. (1967). Heritable dysmorphic syndrome with normal intelligence. Fournal of Pediatrics, 70, 927935.

Kind, H. P. (1970). Popliteales pterygiumsyndrom. Helvetica Paediatrica Acta, 25, 508-516.

Klein, D. (1962). Un curieux syndrome héréditaire: Chéilopalatoschizis avec fistules de la lèvre inférieure associé à une syndactylie, une onychodysplasie particulière, un ptérygion poplité unilatéral et des pieds varus équins. Fournal de Génétique Humaine, 11, 65-71.

Kopits, E. (1937). Die als 'Flughaut' bezeichneten Missbildungen und deren operative Behandlung. Archiv für Orthopaedische und Unfall-Chirurgie, 37, 539-549.

Lewis, E. (1948). Congenital webbing of the lower limbs. Proceedings of the Royal Society of Medicine, 41, 864. 
Marquardt, W. (1937/1938). Die angeborene Flughautbildung und ihre konservative Behandlung. Zeitschrift fïr Orthopädie und ihre Grenzgebiete, 67, 379-386.

Matolcsy, T. (1936). Ueber die chirurgische Behandlung der angeborenen Flughaut. Archiv für Klinische Chirurgie, 185, 675681 .

O'Brien, B. McC., Garson, O. M. Baikie, A. G., and Dooley, B. J. (1970). Multiple congenital skin webbing with cutis laxa. British fournal of Plastic Surgery, 23, 329-336.

Pfeiffer, R. A., Tünte, W., and Reinken, M. (1970). Das Kniepterygium-Syndrom. Zeitschrift für Kinderhei kunde, 108, 103-116.

Rosselli, D. and Gulienetti, R. (1961). Ectodermal dysplasia. British fournal of Plastic Surgery, 14, 190-204.
Rydygier, L. (1891). Demonstration von Abbildungen seltener Fälle von Missbildungen, Archiv für klinische Chirurgie, 42, 769.

Schönenberg, H. (1955). Ueber die Kombination von LippenKiefer-Gaumen-Spalten mit Extremitätenmissbildungen. Zeıt schrift für Kinderheilkunde, 76, 79-90.

Schramm, G. (1940). Ueber die angeborene Flughautbildung. Zeitschrift für Orthopädie und ihre Grenzgebiete, 70, 189-195.

Smith, D. W. (1970). Recognizable Patterns of Human Malformation. (Major Problems in Clinical Pediatrics, Vol. VII.) Saunders, Philadelphia.

Trélat, U. (1869). Cited by Smith (1970).

Wolff, J. (1889). Ueber einen Fall von angeborener Flughautbildung. Archiv für klinische Chirurgie, 38, 66-73. 